Irish post-primary students' attitudes towards ethnic minorities

Roland Tormey and Jim Gleeson

(post print version -

published in Irish Educational Studies,

Volume 31, Issue 2, 2012, pp. 157-173

http://www.tandfonline.com/doi/full/10.1080/03323315.2012.676234) 


\title{
Irish post-primary students' attitudes towards ethnic minorities
}

\begin{abstract}
The changing ethnic make-up of Irish society has impacted upon schools. Existing, largely qualitative studies have highlighted mixed attitudes towards ethnic minorities. Literature has also focussed on the role of the state in articulating a discourse that shapes school-level responses to minorities. This paper critiques the idea of a unitary state discourse and the role of other educational bodies, such as schools, in drawing upon a range of alternate public discourses to shape how they act, is identified. Drawing upon a large quantitative study involving 4,970 post-primary pupil respondents, this paper finds that many Irish post-primary students report low levels of social distance from Black African Immigrants, Muslims, and Eastern Europeans. Negative attitudes are most prevalent with respect to members of the Travelling community. The potential positive impact of school-level programmes - such as those related to global justice and inequalities - is identified through the lower levels of negative attitudes towards ethnic minorities reported by Transition year students who have experienced such programmes.
\end{abstract}

Keywords: ethnicity, intercultural education, curriculum, Transition Year, education policy 


\section{Irish post-primary students' attitudes towards ethnic minorities: findings from a large quantitative study}

\section{Introduction}

In the mid-1990s immigration overtook emigration in Ireland and as a result, pupils now reaching the end of their second-level schooling have grown up in an immigrant society characterised by greater degrees of ethnic and linguistic diversity. This change from a country which was largely regarded as mono-ethnic into a visibly ethnically diverse country in the space of just fifteen years raised questions about the tolerance and engagement of the first Irish generation that have grown up in this self-consciously diverse society and about how their educational experiences are equipping them to live in that society. These are the questions that this research addresses.

This paper first engages with the growing literature on ethnic diversity in education in the Irish context, and offers a critical re-evaluation of some of the theoretical positions articulated there. The empirical component of this paper is based on the findings of an Irish Aid funded research project, conducted by the authors (Gleeson et al., 2007). Data were collected from 4,970 young people in relation to a diverse range of issues relevant to development education in schools and the related attitudes of young people. This is the largest sample of its type in Ireland in relation to these issues.

\section{Theoretical background}

The Irish nation was, up until the 1990s, often regarded as ethnically and culturally homogeneous though, as McVeigh and Lentin (2002, 21) have argued, "Ireland was never the monoculture it told itself it was". This diversity, which became far more pronounced and visible after 1995 has now been well documented (Smyth et al. 2009, 7; Byrne et al., 2010). By the mid 2000s 15 per cent of the population resident in Ireland was not born there (CS0, 2007: 104). Tormey $(2006,313)$ has identified that, in education, "identity construction needs to be understood as an active process through which actors work to construct their own multiple and overlapping ... identities”. For Tovey et al. (1989, 9), ethnicity is a "symbolic meaning system, a way for a 'people' to organise social reality”; what O’Connell $(1994,113)$ describes as a meaning system in which the criteria for belonging to a particular group can be changed and adapted over time as new meanings become associated with particular cultural markers or 
tokens in particular contexts and times. This process of identity and group formation is intrinsically linked to power (Devine, 2005; 2009; Bryan, 2010). Through the symbolic construction of "in" and "out” groups, access to resources and to social power is restricted to those who are deemed to be “insiders". Such symbolic markers of "ingroup” status can be understood as cultural capital (Bourdieu, 1986; Devine, 2009). But, as Foucault has made clear, neither these identifiers of status nor the capacity to ascribe these meanings to them are fixed:

...central to Foucault's conception of power is its shifting, inherently unstable expression in networks and alliances. Rather than the monolithic view of power... the focus is much closer to Machiavelli's strategic concerns or Gramsci's notion of hegemony as a 'war of manoeuvre' in which points of resistance and fissure are at the forefront (Clegg, 1989: 154-155).

For Foucault, power is not something which is exercised by an all-powerful "sovereign” (the state, the bourgeoisie, white-settled-Roman Catholic Irish, etc.) but is instead negotiated in each interaction as each participant both draws upon and simultaneously seeks to re-define the meaning of particular cultural symbols. In the Irish context, for example, Devine has shown how religion, skin colour, sporting prowess, Irish dancing and the Irish language are seen as important markers of "belonging” in schools and are drawn upon as cultural capital by children and their families (2009, 527-9), while at the same time, the meaning of these markers of belonging is itself the subject of renegotiation by children from majority ethnic backgrounds at the very moment that those from minority backgrounds seek to appropriate them $(2009,530)$.

Those engaged in the work of constructing identity groups can draw on a number of resources, including symbolic or cultural resources as well as economic, legislative or political resources. Both Kitching (2010) and Bryan (2008; 2009; 2010) have focussed on the role of the state in generating or perpetuating a particular discourse of identity, variously referred to as "pop-institutional racism” (Kitching, 2010) and “corporate multiculturalism” (Bryan, 2010). Such a discourse is, they argue, drawn upon in interaction at school level as identity is negotiated and constructed. Both Bryan and Kitching, we argue however, tend to collapse the diverse set of positions articulated by the different arms of and bodies associated with the state as if they were analysable as a single discourse. In a democratic society, the state is not simply an actor in the educational field, but is itself part of a field of power in which competing ideas and 
discourses of identity and belonging are being played out. Competing ideas about ethnic diversity and identity emerging from educational policy and practice documents (such as the primary curriculum of 1999 [Tormey, 2006] and the Intercultural Education Guidelines [2005]); from foreign affairs discourses on human rights and global development (see Batteson and Tormey, 2011, for example) and from labour-marketdriven ideas articulated by other state bodies, should not be treated as if they were the same $^{\mathrm{i}}$. Instead of constructing an edifice of a "grand discourse" (whether conceptualised as pop-institutional racism or corporate multiculturalism) it is probably more appropriate to see education policy in Ireland - in relation to diversity as much as in other areas - as representing something of a muddle (Tormey, 2010) or as an exercise in pastiche, where competing ideas are articulated side by side without any attempt to interrogate the differences (O’Sullivan, 2005). Indeed the analytical difficulties caused by the attempt to construct a grand discourse become evident when one asks what alternate discourses are proposed and how they are different from what is found articulated by state bodies. Bryan (2008) for example, argues that in opposition to the state's intercultural discourse (singular) we need a model of practice which will recognise the need for discomfort, as learners confront their own positions of privilege; will draw upon their real-life examples of structural inequalities, and which will look at inequalities in both global and local contexts. She also argues for a narrative of belonging that replaces a nationalist argumentation with one that places diversity and migration at the heart of the debate. All of these features can already be found in the (state's) Intercultural Education Guidelines (see NCCA, 2005, 11-12; 21-22; 44 as just some examples) ${ }^{\mathrm{ii}}$.

The state is clearly an important player in articulating "legitimate" notions of identity (Tormey, 2006) that frame the rights of children in immigrant families (Devine, 2005/2009). At the same time, context is important (Gleeson, 2010) and the discourses (plural) articulated by different arms of the state are but one set of resources that can be drawn upon in the process of constructing and regulating identity and boundary maintenance in schools. Other resources are also used, both from within the school and from wider society, including those from the meaning systems within which children interact (Mac an Ghaill, 1994; Devine, 2009). Indeed, as Tormey and Gleeson (2012) have argued:

In attending to the development of a sense of citizenship or identity which is reflexive and unbounded by national borders, (while at the same time being 
shaped by national-level responses to globalisation), we cannot ignore the ways in which different school contexts and institutional ideologies provide filters through which notions of the personal, the national and the global are framed.

What do we know about the effect of these processes of identity construction on how groups are identified and in particular on levels of social distance between groups in the post-“Celtic Tiger” Ireland? Qualitative research has presented us with different possibilities with Devine and Kelly (2006) and Devine (2009) reporting a mixed picture where children (and teachers) can articulate discourses of engagement, empathy and equality as well as discourses of exclusion. Bryan (2010) tends to see a more negative picture in which state-level discourses are played out at school-level in ways that produce negative outcomes for children from minority backgrounds. While these studies have undoubtedly a richness of qualitative data, there is a need for complementary quantitative data which might enable us to gauge the impact of these competing tendencies at a national level.

Ireland has a long tradition of research on prejudice and tolerance in relation to minority groups. MacGréil’s landmark studies from the early 1970s and the late 1980s (1977; 1996) found a significant but declining minority nationally who subscribed to the belief of a racial inferiority of 'Black' and 'Coloured' people. He also found during the same time period that negative attitudes towards Travellers increased $(1996,227)$. Curry (2000) administered in Dublin the same Bogardus-social-distance scale used by MacGréil and concluded "large numbers of this sample appear to hold very negative beliefs about refugees” $(1998,146)$. Reasons for such views drew on negative media representations and the belief that many were exploiting the social welfare system and begging. Curry (2000) also found that the greatest social distance scores emerging from his study were in respect of Travellers. McGinnity et al. (2006) have reported from a large study on immigrants' experiences of racism and have highlighted that Black Africans report the highest levels of discrimination, followed by Asians and Eastern Europeans.

While these studies are useful, they tell us nothing about the distinctive culture and perspectives of young people. Lynch and Lodge (2002, 140), in their study of second level schools found that there were strongly negative attitudes towards Travellers, with three-quarters of school-aged young people in their study saying that Travellers would not fit into their school, as compared to 23 per cent who agreed that a black or coloured young person would get bullied in their school. Leavy (2005), in her 
study of Irish pre-service teachers found that, attitudes towards ethnic diversity was somewhat mixed, with student teachers being on average, positively disposed towards friendships across ethnic groups, but showing lower levels of tolerance for societal change to accommodate diversity.

Qualitative research has described the processes of identity formation that are evident in schools, and has highlighted both the role of the state in shaping a discourse [sic] as well as the role of school, academic systems, broader cultural systems, as well as legislative and economic structures (Devine, 2005; Devine and Kelly, 2006; Devine, 2009, Bryan, 2010; Kitching, 2010) in providing resources or capital which are used in the identity construction process. Resulting attitudes are both the product of local processes of identity construction and of resources that is used by young people in such processes. There is, however, a need for quantitative data to enable us to understand the impact of those processes. One of the difficulties evident in large-scale quantitative research - particularly research on social distance - is in how to 'name' the groups towards which social distance is to be measured. Research on identity has tended towards a broad acceptance that identity groups are socially constructed and flexible over time (Barth 1969; Jenkins 1996). In the work carried out by both MacGréil and Curry identification is required of particular groups in respect of which social distance is to be measured. In doing so it may 'reify' such groups as fixed categories. This is all the more problematic in a context such as contemporary Ireland in which group formation for newly arrived immigrants is at an early stage and is likely to be contested. At the same time, there is a value in large-scale quantitative studies in that they provide us with a picture of attitudes across representative groups, that may have been indicated in qualitative research (Keogh 1998; Devine and Kelly 2006; Devine 2009; Bryan 2010). It is also notable that, despite being over seventy-years old the Bogardus scale model continues to be regarded as sound once reliability and validity data is reported upon (Brown 2004).

Indeed, what quantitative data exists tells us little about young people's attitudes to minorities in this changed environment: large studies like the previously mentioned studies conducted by MacGréil, Curry or Lynch and Lodge predate these changes and some focus on adults rather than on young people's attitudes. While qualitative data can describe for us the process found in schools it cannot really allow us to gauge their overall impact. These are the issues that this research addresses. 


\section{Methodology}

\section{Research Questions}

The questions which this paper addresses are:

1. What is the level of social distance reported by young people with respect to a number of different ethnic, religious and 'place of origin' minority groups?

2. How does this vary depending on school-year cohort, gender and gender intake of school?

3. Is there any relationship between their reported school-based experiences and their reported levels of social distance?

\section{Population}

This research is based on the largest ever study of attitudes to ethnic minorities carried out among young people in Ireland. Data was collected from survey instruments administered to 2,588 second-year and 2,382 fifth-year (first-year Leaving Certificate) post-primary students. A sample of 120 (out of 743) schools was selected in order to ensure a representative sample of students and teachers. Following withdrawals and replacements, 119 schools participated in the study. Classes within the school were identified at random and students completed the survey during a timetabled class time, overseen by a class teacher, in late 2006 and early 2007.

Boys made up 44.0 per cent of the sample with girls accounting for 56.0 per cent. In the second-year cohort ${ }^{\mathrm{iii}}$, students in single-sex schools are slightly overrepresented in the sample, with students in co-educational schools accounting for 54.1 per cent of the sample and 62.4 per cent of the population. Girls in single-sex schools make up 25.2 per cent of the sample as compared to 22.2 per cent of the population, and boys in single-sex schools make up 20.7 per cent of the sample as compared to 15.4 per cent of the population. Broadly speaking then, the sample is representative of the population of Irish post-primary school pupils.

\section{Instrument}

The survey included questions on basic demographic data of the pupils, their knowledge of development issues, their attitudes towards development issues and ethnic minorities, their experience of addressing development issues in school and their levels of activism in relation to development issues. The instrument was developed by the research team, in consultation with a number of teachers and educationalists. In 
particular attention was paid to the age appropriateness of the questions and to their intelligibility to pupils. The instrument was also piloted with a group of pupils to test for intelligibility.

The data on the pupils' attitudes to ethnic minorities was based on an adapted version of the Bogardus-type scale used by MacGréil and others. The authors adapted this scale and, with respect to each of the above groups, asked respondents if they would:

o be happy if members of this group moved in next door to them

0 be happy to have a member of this group in their class

o be happy to have a member of this group living in their street or neighbourhood

o prefer if all the members of this group left the country

The adaptations were undertaken to ensure the age appropriateness of the instrument, and means that the data is not directly comparable with the previous work of MacGreil 1996 or Curry 2000. Care was also taken to ensure that the groups from whom social distance was to be measured were meaningful to the majority of pupil respondents. This means that the groups identified are not necessarily specifically identified ethnic groups, but are instead a mixture of 'place of origin' groups, religious groups and ethnic groups $^{\text {iv }}$ (the categories used are 'Traveller', 'Muslim’, 'Eastern European’, 'Black African Immigrant', referred to in this paper as 'ethnic' groups).

Each scale was tested for reliability (using Crombach's alpha) and for validity (using face validity, and factorial validity criteria). A Crombach's alpha score of higher than 0.7 is usually taken as an indication of a very reliable scale. All scales in this case score well above 0.7 . Validity is confirmed both through ensuring a logical consistency between the items (face validity) and through inter-item correlation scores (factorial validity). As may be seen from the following, the validity of the scales is confirmed in respect of both Crombach's alpha and inter-item correlation.

o For the Social Distance from Black African Immigrants Scale for the secondyear cohort the Crombach's alpha was 0.823 while the inter-item correlation scores ranged from 0.421 to 0.702 . For the fifth-year cohort, the Crombach's alpha score was 0.838 while the inter-item correlation scores ranged from 0.439 to 0.683 .

o For the Social Distance from Eastern Europeans Scale for the second-year cohort, the Crombach's alpha score was 0.837 , while the inter-item correlation 
scores ranged from 0.395 to 0.742 . For the fifth-year cohort the Crombach's alpha score was 0.849 , while the inter-item correlation scores ranged from 0.521 to 0.753 .

o For the Social Distance from Muslims Scale for the second-year cohort, the Crombach's alpha score was 0.9 while the inter-item correlation scores ranged from 0.613 to 0.815 . For the fifth-year cohort the Crombach's alpha score was 0.868 while the inter-item correlation scores range from 0.507 to 0.793 .

o For the Social Distance from Travellers Scale for the second-year cohort the Crombach's alpha score was 0.843 while the inter-item correlation scores ranged from 0.432 to 0.772 . For the fifth-year cohort the Crombach's alpha score was 0.806 and the inter-item correlation scores ranged from 0.378 to 0.623 .

Students born outside Ireland accounted for 11.8 per cent of the overall sample, with more than half of these being born in the UK. Whether or not pupils were born in Ireland was not found to be associated with their levels of reported social distance and so this does not form part of the analysis presented here.

\section{Results}

\section{Levels of social distance reported}

Insert figure 1 here

The results of the social distance scale are presented in Figure 1. The majority of students expressed no social distance (a score of zero) with respect to most minority groups with 74 per cent reporting no social distance from Black African Immigrants, and 64 per cent reporting no social distance from Eastern Europeans or Muslims. A higher proportion identify a strong sense of social distance from Muslims than from either Black African Immigrants or Eastern Europeans, with 18 per cent of respondents having a high or very high social distance score with respect to Muslims (as compared to 9 percent in the case of Black African Immigrants and 16 per cent in the case of Eastern Europeans). The case of the Traveller community is notably different from other minority ethnic groups. Only 27 per cent of respondents expressed no sense of social distance from members of the Traveller community. The modal average social distance score from members of the Traveller community was a 'moderate' score (2 on a 0-4 range). Overall 26 per cent of the cohort expressed a very high level of social 
distance from members of the Traveller community, with a further 16 per cent expressing 'high' levels of social distance (this means 42 per cent of respondents expressed ‘high’ or ‘very high’ levels of social distance from Travellers).

\section{School year, gender and variations in social distance reported}

There were few differences reported between the second- and fifth-year cohorts on reported social distance scales. For Black African Immigrants and Eastern Europeans the figures for fifth-year pupils are almost identical to the younger group, for Muslims and Travellers there is a slightly higher degree of polarisation; the percentage of respondents with no social distance and the percentage with a very high social distance is greater among the fifth-year cohort.

Differences emerged between male and female students in terms of their reported levels of social distance (meaning girls, on average, report lower levels of social distance than boys). Among the second- year students this association was only found with respect to reported social distance from members the Traveller community. The association is weak, but is statistically significant (Chi-square $=13.67, \mathrm{df}=1, \mathrm{p}<$ 0.01, Cramer's V = 0.084).

Gender differences were most evident in the fifth-year cohort where sex of respondent was statistically significantly associated with scores on all four social distance scales. The associations are of weak to moderate strength and can be most easily seen at either extreme of the scales, such as are presented in Figure 2. In all cases it is clear that girls are more heavily represented among those with no social distance from minority ethnic groups and boys are more heavily represented among those with very high levels of social distance from minority ethnic groups. Indeed, the proportion of boys among those with very high levels of social distance from minority ethnic groups is typically twice that of girls, with over a third of boys scoring very high on the social distance from Travellers scale, as compared to under 18 per cent for girls.

In relation to other contextual independent variables, it is notable that there is little variation in the pattern of scores on the social distance scales. In other words, in the patterns of social distance evident above broadly hold true irrespective of gender of school intake, school type and school size.

[Insert Figure 2 here]

\section{School experiences and reported level of social distance}


Students were asked if they had ever discussed a range of development-related topics in school, including 'aid and development', 'Irish missionaries', and 'racism, refugees and migration'. Fifth-year students were also asked if they had taken Transition Year (Transition Year [Jeffers 2007] is taken by some 40 per cent of Irish students between their second-level junior cycle state examinations, taken at age 15, and the start of their senior cycle state examination two-year cycle; Transition Year tends to be marked by a more integrated curriculum, and more student-centred learning than is the case in the years which form part of the state examination cycles). There is, across both secondand fifth-year cohorts a similar pattern of weak but significant relationships between the extent to which students have discussed development-related issues in school and their scores on social distance scales. Figure 3 reports the Cramer's V scores for the associations between discussing these issues in school and the student's reported level of social distance from the ethnic minority groups (as above, Cramer's V is used as the independent variables are nominal in nature). Only the fifth-year data is presented, given the patterns are the same in both cohorts. In these cases, the relationships are all of low to moderate strength; however all are significant at - at least - the 0.05 level. The strongest association is with having discussed 'racism, refugees and migration' in school and the weakest association was with discussing 'Irish missionaries'. With respect to having undertaken Transition Year there is, again, a pattern of moderately strong relationships; in other words, students who have taken transition year tend to exhibit lower levels of social distance from all minorities. Of course, this relationship could be to do with the maturity of this group in so far as they will tend to be one-year older than those who have not taken transition year. It may also have to do with social class and academic ability factors, given the characteristics of those who take Transition Year (Jeffers, 2007). In fact, age turns out not to be the defining factor here; the strength of the relationships between having taken Transition Year and social distance scores is slightly weaker when age is controlled for (by looking at only the 16-year old respondents) but the relationships remain significant.

Insert figure 3 about here

\section{Discussion}


The issues considered in this section include social distance from Travellers; the influence of two key factors, gender and participation in Transition Year; the positive value of development education and challenges facing Traveller education.

\section{Social distance from ethnic minority groups}

The data presented here gives, for the first time, a clear account of the levels of social distance reported by Irish post-primary school pupils across a range of different ethnic minority groups. Previous qualitative based analyses has suggested a continuum of responses to minority ethnic groups - ranging from high levels of social distance (Bryan 2009/2010) to more mixed responses (MacGréil, 1996; Curry, 2000; Leavy, 2005; Devine and Kelly, 2006; Devine 2009). Our study suggests that reported social distance levels to a range of ethnic minority groups are relatively low among the post-primary students sampled. For example, three-quarters reported no social distance from Black African Immigrants while two-thirds reported no sense of social distance from Eastern Europeans or Muslims. In stark contrast, however, only 27 per cent of respondents expressed no sense of social distance from members of the Traveller community while 26 per cent reported very high levels of social distance from Travellers (this means for example that these post-primary students agreed with all four statements including ' $I$ would prefer if Travellers all left the country'). The figures related to Black African

Immigrants and Travellers tally almost exactly with those reported by Lynch and Lodge (2002, 140) and the findings are broadly consistent with the findings of Curry (2000) and MacGréil (1996). Mac an Ghaill (1999) has noted that the dominance of North American concepts within discussions of ethnicity have tended to lead to a prioritising of skin colour as being the primary basis of discrimination. He argues that this tends to lead to 'white-white' social distance and discrimination to be overlooked. The same arguments might be made in relation to this Irish data: it is clear that fewer Irish young people report a high degree of social distance to Black African Immigrants than is the case with respect to Eastern Europeans, Muslims and, members of the Irish Traveller community. It would be worth considering this in more detail, however: McGinnity et al. (2006) present a slightly different picture when they highlight that, of immigrant groups, Black Africans report the highest levels of discrimination in Ireland, followed by Asians and Eastern Europeans. It may be that an awareness by our respondents that racist attitudes towards black people are seen as socially undesirable has led to an underreporting of their actual levels of social distance towards immigrant groups. In a 
sense, however, this simply makes our findings with respect to social distance from Travellers even more shocking: if the pupils’ responses actually underreport social distance then either (a) the actual levels of social distance to members of the Traveller community may be even higher, or (b) participants had no difficulty in reporting their levels of social distance from Travellers because negative attitudes towards Travellers are regarded as socially acceptable.

\section{Gender differences}

Gender emerges as an important variable in making sense of the patterns of social distance observed. Again, this is consistent with what was found by Lynch and Lodge (2002, 144) and with the pattern seen in Crotty's data (2000). Our larger data set however allows for more detail on these gendered patterns to be seen. The association between gender and reported social distance scores was highest with respect to the Traveller Community, followed by Black African immigrants and lowest with respect to Eastern Europeans. It is notable and worrying that the gendered nature of the patterns becomes more evident over time, with far fewer gender-related differences in reported levels of social distance being evident at second-year level than at fifth-year level. More generally, one difference that did emerge between the second- and fifth-year groups was that the fifth-years were more polarised in their reported attitudes towards Muslims and Travellers. Combined, these findings related to gender, raise worrying questions about the hardening of negative attitudes over the course of boys' lives in school. Existing studies have highlighted that girls' schools have tended to place greater emphasis on a sense of care for others in the community (Lynch and Lodge, 2002). However in the current study the association is between social distance and gender per se, rather than with the gender of the school intake, (in the current study no significant relationship was found between gender of school intake and social distance).

The data does suggest a need for a particular focus on the socialisation processes at work in the lives of young men. The 'Exploring Masculinities' programme, piloted some ten years ago, included sections on bullying and attitudes towards minority groups. While the programme was found to work well in schools (Gleeson, Conboy and Walsh, 2003; Mac an Ghaill, Conway and Hanafin, 2005) and its contents were welcomed by parents (McCormack, 2010), it has fallen into disuse following objections from a small number of parents and some high profile journalists (McCormack, 2010). 
The extension of Social, Personal and Health Education to senior cycle has been awaited now for a considerable length of time.

\section{Potentially positive value of educational programmes}

As was noted above prior research has highlighted both the role of the state in shaping discourses about belonging (Devine, 2005; Tormey, 2006; Bryan, 2010; Kitching, 2010) and the role of school, academic and broader cultural, political and economic factors (Devine and Kelly, 2006; Devine, 2009) in providing resources or capital which are used in the identity construction process. The research team collected data on some educational processes and were able to ascertain their association with levels of social distance. While the data collected reflects a very minimal standard of activity (i.e., whether or not pupils remember having discussed an issue in school) it does show that reporting engagement in even a low level of educational activity is associated with lower levels of reported social distance to a range of minority ethnic groups. The data only tells us that an association exists; it does not tell us that such experiences have caused a drop in reported levels of social distance. It is conceivable, for example, that those with lower levels of social distance were also those who were predisposed to engaging more with development education experiences and, as such, were more likely to report having had such experiences. Nonetheless, the data is important in raising questions around the possibility that even a minimal level education activity might have some positive impact upon reported sense of social distance.

It is notable that students who took Transition Year also reported lower levels of social distance from members of ethnic minorities than those who had not taken Transition Year, and that this holds true even when controlling for age. Since it can be presumed that students would remember if they had taken Transition Year, and since the Transition Year effect is evident even when age is controlled for, at least some of the possible intervening variables here can be controlled for. It should be noted that social class is not controlled for here and that those from higher socio-economic groups are more likely to take Transition Year (Smyth et al. 2004, 47; Jeffers, 2002). This may be a contributory factor to the 'Transition Year effect', although the evidence in relation to other sorts of positive outcomes for Transition Year suggests that positive effects remain even when the full range of intervening variables are controlled for. The aims of Transition Year include (1) education for maturity with an emphasis on personal development, (2) the promotion of general, technical and academic skills with an 
emphasis on interdisciplinarity and (3) education through experience of working life (Smyth et al. 2004, 58; Jeffers, 2007). Transition year is often a site for educational work on development and social justice issues. In their evaluation of Transition Year, Smyth et al. identify that "data are not available to assess the impact of participation [in transition Year] on the personal development and "soft skills" of student [though] perceptions of the success of the programme in these respects are broadly positive" (2004, 212). Jeffers $(2008,253)$ found that 'a consistent thread through the data from all information is that students are more mature as a result of the TY experience'. He goes on to report 'strong evidence that TY promotes young people's confidence, improves bonds between classmates and facilitates better relations between students and teachers'. Regrettably Travellers as a group are most unlikely to participate in Transition Year.

Our data does seem to confirm the positive effect of Transition Year on one aspect of social development - the levels of reported social distance from minority groups. Given that only about 40 per cent of students actually get to undertake Transition Year, this raises questions as to how a comparable focus on personal development and interdisciplinary, multi-site learning can be made more generally available in Irish schools.

\section{Conclusion and recommendations}

Ireland has changed rapidly in the last two decades and the generation now leaving second-level schools have grown up in an environment which is self-consciously different to that of previous generations. Existing research on student perceptions much of it qualitative - has highlighted the processes of identity and group formation which take place in schools. We have argued in this paper that the portrayal of a single grand overarching state discourse on identity is flawed and may lead to overly pessimistic accounts of inter-group relationships in schools. Taking account of a more mixed picture of how schools, teachers and children all play active roles in articulating discourses of engagement, empathy and equality as well as discourses of exclusion is more fruitful.

Our study adds to the growing body of literature in the area providing the largest data set available on the attitudes and experiences of second level students in Ireland toward ethnic minorities. It shows relatively low levels of reported social distance from immigrant ethnic minority groups in modern Ireland (especially with respect to Black 
African Immigrants and Eastern Europeans) and higher levels of social distance from Muslims but most especially from Travellers. While these findings mirror to some extent those of MacGréil (1996), he found that social distance levels increased with age in the broader population. In our research however, the youthfulness of these students has not made a difference. Indeed, within the fifth-year group there were higher levels of polarisation in attitudes towards some of the minority ethnic groups addressed by this study. We also found that where schools were reported as providing even a minimal level of educational activity which addressed globalisation, inequality and diversity issues, this was associated with lower levels of reported social distance.

A number of clear recommendations can be made based on this study. While there are some young people that report negative attitudes towards a range of different minority groups, for most young people Irish Travellers are perceived differently to other ethnic minorities. The levels of reported negativity towards Irish Travellers are disturbing and need to be urgently addressed by our education system. In doing so, it would make sense to highlight that discrimination against white ethnic minorities (what Mac an Ghaill [1999, 77] refers to as 'racism without race') is just as undesirable as discrimination against black ethnic minorities. In this respect, dealing with Travellers and immigrant minorities through a separate set of policies and procedures may actually reinforce the perception that Travellers are in some way in a different category. This may, as such, be counterproductive. This is not to suggest that educational activity alone can overcome anti-Traveller bias - or any bias - out of existence. As Gillborn has argued: "In isolation...no field of social policy can eradicate racism from society: racism gains strength from too many quarters simply to be 'taught out of existence"” (1995, 2). Notwithstanding this, school can: "make its distinctive contribution by tackling the intellectual and moral basis of racism that is amenable to and indeed falls within its purview” (Parekh 1986, 31). The recognition of such a broader context should not blind us to the possibilities for action that continue to exist within the educational context.

The need for a particular focus on social and personal education with boys has been recognised in the existence of programmes like 'Exploring Masculinities'. That the programme has been allowed to fall into disuse is regrettable. This is not to suggest that intercultural education or social and personal education for girls is not equally important, but rather it is to suggest that the relationship between gender socialisation and ethnic identification in schools, is worthy of particular attention. In doing this, 
there needs to be a focus across both single-sex and co-educational schools, as school type is not, in itself, associated with higher levels of reported social distance. There are clear grounds for arguing that educational experiences that are directed towards personal development and discussion of global development, poverty, discrimination and ethnicity issues may have an impact on reducing reported levels of social distance. The challenge to educational policy shapers is how to ensure that the personal and social development opportunities that can be found within Irish curricula are given greater prominence and become a more central part of young people's experience of school.

Irish demography has changed rapidly over the last decade and a half. The data presented here complements and extends existing qualitative studies and highlights the nature of the challenge that faces us if we are to prepare young people adequately for the world they already live in.

\section{References}

Barth, F. 1969. Introduction. In Ethnic Groups and Boundaries: The Social organisation of cultural difference, ed. Barth, F. Oslo: Universitetforlaget.

Batteson, T. and Tormey, R. Eds. 2011. Teaching Global Perspectives; Introducing Student Teachers to Development Education. Dublin: Liffey Press.

Bourdieu, P. 1986. The forms of capital. In Handbook of theory and research for the sociology of education, ed. J.G. Richardson. New York: Greenwood Press, 4658 .

Brown, K. M.2004. Assessing Preservice Leaders' Beliefs, Attitudes, and Values Regarding Issues of Diversity, Social Justice, and Equity: A Review of Existing Measures. Equity \& Excellence in Education 37: No. 4: 332 - 342.

Bryan, A. 2008. The co-articulation of national identity and interculturalism in the Irish curriculum: educating for democratic citizenship? London Review of Education, 6: No.1: 47-58.

Bryan, A. (2009) The intersectionality of nationalism and multiculturalism in the Irish curriculum: teaching against racism? Race Ethnicity and Education. 12: No. 3: 297-317.

Bryan, A. (2010) Corporate multiculturalism, diversity management, and positive interculturalism in Irish schools and society. Irish Educational Studies. 29: No. 3: 253-269.

Byrne, D., McGinnity, F., Smyth, E., Darmody, M. (2010) Immigration and school composition in Ireland. Irish Educational Studies. 29: No. 3: 271-288.

Clegg, S. 1989. Frameworks of Power. London: Sage.

CSO, The Central Statistics Office. 2007. Census 2006, Volume 4 - Usual residences, Migration, Birthplace, Nationalities. Dublin: Stationery Office.

Curry, P. 2000. “.... she never let them in”. Popular reactions to refugees arriving in Dublin. In Cultivating Pluralism. Psychological, Social and Cultural Perspectives on a Changing Ireland, eds. MacLachlan, M. And M O’Connell. Dublin: Oak Tree Press, 137-152. 
Devine, D. 2005. Welcome to the Celtic Tiger? Teacher responses to immigration and increasing ethnic diversity in Irish schools. International Studies in Sociology of Education. 15: No. 1: 49-70.

Devine, D. 2009. Mobilising capitals? Migrant children's negotiation of their everyday lives in school. British Journal of Educational Sociology. 30: No. 5: 521-535.

Devine, D. and Kelly, M. (2006) 'I just don't want to get picked on by anybody': Dynamics of inclusion and exclusion in a newly multi-ethnic Irish primary school. Children \& Society, 20: 128-139.

Gillborn, D (1995) Racism and Antiracism in Real Schools. Buckingham: Open University Press.

Gleeson, J. 2010. Curriculum in Context. Partnership, Power and Praxis in Ireland. Oxford: Peter Lang

Gleeson, J., Conboy, P. \& Walsh, A. 2004. The piloting of Exploring Masculinities, 1997-1998. Dublin: Stationery Office.

Gleeson, J., P. King, S. O’Driscoll, and R. Tormey. 2007. Development education in Irish post-primary schools, knowledge, attitudes and activism, Shannon: Shannon Curriculum Development Centre; Limerick: Curriculum Evaluation and Policy Research Unit, University of Limerick.

Government of Ireland 1995 Report of the Task Force on the Travelling Community.

Dublin: Stationery Office.

Jeffers, G. 2002. Transition Year Programme and Educational Disadvantage, Irish Educational Studies, 21 (2) p.47-64

Jeffers, G. 2007. Attitudes to Transition Year, Summary of a Report to the Department of Education, Education Department, NUI Maynooth.

Jeffers, G. 2008. Innovation and Resistance in Irish Schooling: The Case of Transition Year. PhD thesis submitted to University of Limerick

Jenkins, R. 1996. Social Identity. London: Routledge.

Keogh, A. 2000. Talking about the other: a view of how secondary school pupils construct opinions abour refugees and asylum-seekers. In Cultivating Pluralism. Psychological, Social and Cultural Perspectives on a Changing Ireland, eds. MacLachlan, M. And M O’Connell. Dublin: Oak Tree Press, 123137

Kitching, K. 2010. An excavation of the racialised politics of viability underpinning education policy in Ireland. Irish Educational Studies. 29: No. 3: 207-213.

Leavy, A. 2005. "When I meet them I talk to them': the challenges of diversity for preservice teacher education. Irish Educational Studies 24 No. 2: 159 - 177.

Lynch, K. and A. Lodge. 2002. Equality and Power in Schools. Redistribution, Recognition and Representation. London: RoutledgeFalmer.

Mac an Ghaill, M. 1994. The Making of Men. Buckingham: Open University Press.

Mac an Ghaill, M. 1999. Contemporary Racisms and Ethnicities Buckingham: Open University Press.

Mac an Ghaill, M., Hanafin, J., and Conway, P. F. 2004. Gender politics and Exploring Masculinities in Irish Education: Teachers, materials and the media. Dublin: National Council for Curriculum and Assessment (NCCA)

McCormack, O. 2010. Exploring Masculinities, The Sequel: An exploration of the views and attitudes of Irish parents and a sample of journalists towards the exploration of masculinities with young men at senior cycle. $\mathrm{PhD}$ thesis submitted to University of Limerick. 
McGinnity, F., P. O’Connell, E. Quinn, and J. Williams. 2006 Migrants Experience of Racism and Discrimination in Ireland. Dublin: Economic and Social Research Institute.

MacGréil, M. 1977. Prejudice and Tolerance in Ireland. Dublin: College of Industrial Relations.

MacGréil, M. 1996. Prejudice in Ireland Revisited. Maynooth: Survey and Research Unit, St Patrick's College.

McVeigh, R. and R. Lentin. 2002. Situated racisms: a theoretical introduction. In Racism and Anti-Racism in Ireland, eds. R. Lentin and R. McVeigh. Belfast: Beyond the Pale Publications, 1-49.

NCCA, National Council for Curriculum and Assessment. 2005. Inter-Cultural Education in the Primary School. Guidelines for Schools. Dublin: National Council for Curriculum and Assessment.

NCCA, National Council for Curriculum and Assessment. 2006. Inter-Cultural Education in the Post-Primary School. Guidelines for Schools. Dublin: National Council for Curriculum and Assessment.

Parekh, B. 1986. The Concept of Multi-Cultural Education. In Mogdil, S., Verma,G., Mallick, K. and Mogdil, C. (Eds.) Multicultural Education, The Interminable Debate. Lewes and Philadelphia, Falmer Press.

Smyth, E., D. Byrne and C. Hannan. 2004. The Transition Year Programme, An Assessment. Dublin: The Liffey Press.

Smyth, E., M. Darmody, F. McGinnity, D. Byrne. 2009. Adapting to Diversity: Irish Schools and Newcomer Students. Dublin: Economic and Social Research Institute.

Tormey, R. 2006. The construction of national identity through primary school history: the Irish case. British Journal of Sociology of Education 27, No. 3: 311-324.

Tormey, R. 2010. The silent politics of educational disadvantage and the National Antipoverty Strategy. Irish Educational Studies. 29: Vol. 2: 189-199.

Tormey, R. and Gleeson, J. (2012) The Gendering of Global Citizenship: findings from a large-scale quantitative study on global citizenship education experiences. Gender and Education (DOI:10.1080/09540253.2011.646960)

Tovey, H. and P. Share. 2000/2003. A Sociology of Ireland, Second Edition. Dublin: Gill and Macmillan.

Tovey, H., Hannan, D. and Abramson, H. 1989. Cad Chuig an Gaeilge? Language and Identity in Ireland Today: Dublin: Bord na Gaeilge. 
Figure 1: Respondents' Levels of Social Distance from a Range of 'Ethnic'

\section{Minority Groups}

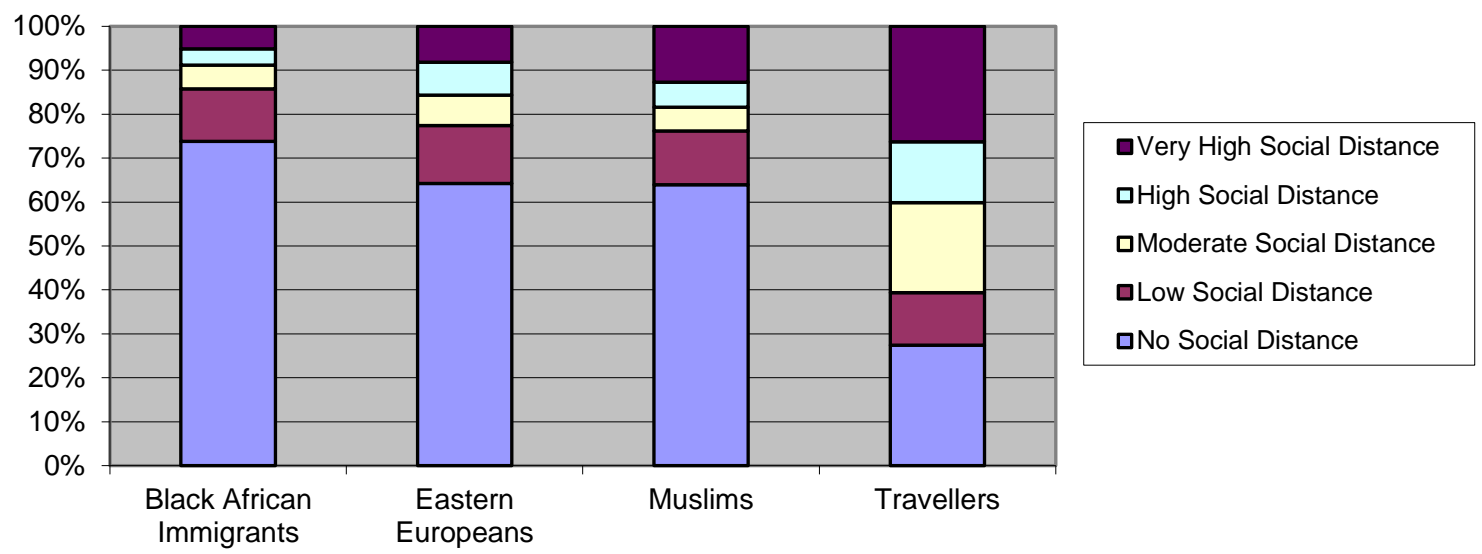

Note: Chart is based on valid percentages. Social Distance from Black African Immigrants Scale, N=4,645; Social Distance from Eastern Europeans Scale, N=4,614; Social Distance from Muslims Scale, N=4,717; Social Distance from Travellers Scale, $\mathrm{N}=4,717$ 
Figure 2: Gender of respondents and Scores on Social Distance Scales (fifth-year cohort)

\begin{tabular}{|c|c|c|c|c|}
\hline & & $\begin{array}{ll}\text { Percentage of } \\
\text { Female } \\
\text { Respondents }\end{array}$ & $\begin{array}{lll}\text { Percentage of } & \text { Total } \\
\text { Male } & & \\
\text { Respondents } & & \\
\end{array}$ & \\
\hline Black African & $\begin{array}{ll}\text { No } & \text { Social } \\
\text { Distance } & \end{array}$ & 80.4 & 69.6 & 75.7 \\
\hline $\begin{array}{l}\text { Immigrants } \\
(\text { Cramer's V = } \\
0.146 ; \text { p. }<0.001)\end{array}$ & $\begin{array}{l}\text { Very High Social } \\
\text { Distance }\end{array}$ & 2.7 & 7.7 & 4.9 \\
\hline $\begin{array}{l}\text { Eastern } \\
\text { Europeans }\end{array}$ & $\begin{array}{ll}\text { No } & \text { Social } \\
\text { Distance } & \end{array}$ & 67.5 & 60.9 & 64.6 \\
\hline $\begin{array}{l}\text { (Cramer's V }= \\
0.084 ; \text { p. }<0.01 \text { ) }\end{array}$ & $\begin{array}{l}\text { Very High Social } \\
\text { Distance }\end{array}$ & 6.7 & 10.6 & 8.4 \\
\hline $\begin{array}{l}\text { Muslims } \\
\text { (Cramer's V = }\end{array}$ & $\begin{array}{ll}\text { No } & \text { Social } \\
\text { Distance } & \end{array}$ & 66.7 & 57.8 & 68.2 \\
\hline $0.119 ;$ p. $<0.001)$ & $\begin{array}{l}\text { Very High Social } \\
\text { Distance }\end{array}$ & 8.3 & 15.2 & 11.3 \\
\hline $\begin{array}{l}\text { Travellers } \\
\text { (Cramer's V = }\end{array}$ & $\begin{array}{ll}\text { No } & \text { Social } \\
\text { Distance } & \end{array}$ & 30.1 & 19.1 & 25.3 \\
\hline $0.199 ;$ p. $<0.001)$ & $\begin{array}{l}\text { Very High Social } \\
\text { Distance }\end{array}$ & 17.8 & 33.7 & 24.8 \\
\hline
\end{tabular}

Note: For Social Distance from Black African Immigrants $N=2,207$; for Social Distance from Eastern Europeans $N=2,224$; for Social Distance from Muslims $N=2,260$; for Social Distance from Travellers, $N=2,261$. Cramer's $\mathrm{V}$ is used here because the independent variable is nominal data - Cramer's $\mathrm{V}$ ranges from zero [no association] to 1 [perfect association])

Figure 3: Cramer's V scores and significance levels for relationships between social distance scores and issues addressed in school, or taking Transition Year (fifth- year cohort)

\begin{tabular}{|l|l|l|l|l|l|}
\hline & $\begin{array}{l}\text { Aid and } \\
\text { Development }\end{array}$ & $\begin{array}{l}\text { Irish } \\
\text { Missionaries }\end{array}$ & $\begin{array}{l}\text { Racism, } \\
\text { refugees and } \\
\text { migration }\end{array}$ & $\begin{array}{l}\text { Transition } \\
\text { Year }\end{array}$ & $\begin{array}{l}\text { Transition } \\
\text { Year } \\
\text { (controlled for } \\
\text { age })\end{array}$ \\
\hline $\begin{array}{l}\text { Social Distance } \\
\text { from Black }\end{array}$ & $\begin{array}{l}0.101 \\
(\mathrm{p} .<0.01)\end{array}$ & $\begin{array}{l}0.099 \\
(\mathrm{p} .<0.01)\end{array}$ & $\begin{array}{l}0.186 \\
(\mathrm{p} .<0.001)\end{array}$ & $\begin{array}{l}0.172 \\
(\mathrm{p} .<0.001)\end{array}$ & $\begin{array}{l}0.140 \\
(\mathrm{p} .<0.001)\end{array}$ \\
\hline $\begin{array}{l}\text { Immigrants } \\
\text { Social Distance } \\
\text { from Eastern }\end{array}$ & $\begin{array}{l}0.191 \\
(\mathrm{p} .<0.001)\end{array}$ & $\begin{array}{l}0.125 \\
(\mathrm{p} .<0.001)\end{array}$ & $\begin{array}{l}0.212 \\
(\mathrm{p} .<0.001)\end{array}$ & $\begin{array}{l}0.291 \\
(\mathrm{p} .<0.001)\end{array}$ & $\begin{array}{l}0.185 \\
(\mathrm{p} .<0.001)\end{array}$ \\
\hline $\begin{array}{l}\text { Europeans } \\
\text { from Muslial Distance }\end{array}$ & $\begin{array}{l}0.161 \\
(\mathrm{p} .<0.001)\end{array}$ & $\begin{array}{l}0.079 \\
(\mathrm{p} .<0.05)\end{array}$ & $\begin{array}{l}0.149 \\
(\mathrm{p} .<0.001)\end{array}$ & $\begin{array}{l}0.216 \\
(\mathrm{p} .<0.001)\end{array}$ & $\begin{array}{l}0.132 \\
(\mathrm{p} .<0.001)\end{array}$ \\
\hline $\begin{array}{l}\text { Social Distance } \\
\text { from Travellers }\end{array}$ & $\begin{array}{l}0.078 \\
(\mathrm{p} .<0.05)\end{array}$ & $\begin{array}{l}0.108 \\
(\mathrm{p} .<0.001)\end{array}$ & $\begin{array}{l}0.156 \\
(\mathrm{p} .<0.001)\end{array}$ & $\begin{array}{l}0.216 \\
(\mathrm{p} .<0.001)\end{array}$ & $\begin{array}{l}0.224 \\
(\mathrm{p} .<0.001)\end{array}$ \\
\hline
\end{tabular}

Note: Question asked 'Have you discussed any of the following topics in school?' and required a 'yes/ no/ don't know' answer. 'Don’t know' answers were excluded from this analysis. Control for age achieved by using only 16 year olds $(\mathrm{N}=1,086)$.

\footnotetext{
${ }^{\mathrm{i}}$ In Bryan 2010 there is greater recognition of this diversity but this does not form a significant part of her analysis.

ii It should be noted, that one of the authors of this paper was centrally involved in writing the Intercultural Education Guidelines and was consequently in a position to experience the manner in which diverse discourses around identity and inequality were articulated and played out in that process.
} 
iii For reasons related to how the data was entered, similar figures are not available for the 5th year cohort.

iv A similar process of categorisation took place in the McGinnity et al. [2006] study, with some similar categories being used both in McGinnity et al. and in Devine’s work [2006]). 